\title{
Amphibians of the Oriental Region and the Moulouya River Basin of Morocco: distribution and conservation notes
}

\author{
Youness Mabrouki1 ${ }^{1 *}$, Abdelkhaleq Fouzi Taybi ${ }^{1}$, Ali Skalli², Alberto Sánchez-Vialas ${ }^{3,4}$ \\ ${ }^{1}$ Université Mohamed Premier, Faculté des Sciences, Département de Biologie, Laboratoire des Sciences de \\ l'Eau, de l'environnement et du Développement Durable, B.P. 717, Oujda, Morocco \\ ${ }^{2}$ Université Mohamed Premier, Faculté Pluridisciplinaire de Nador, Observatoire de la lagune de Marchica \\ de Nador et Région Limitrophes, BP 300, 62700, Selouane, Nador, Morocco. \\ ${ }^{3}$ Museo Nacional de Ciencias Naturales, C/ José Gutiérrez Abascal 2, 28006, Madrid, Spain. \\ ${ }_{4}^{4}$ Asociación Bio+. Av. de América, 64, 7B, 28028 Madrid, Spain. \\ *Correspondence: E-mail: younes_mab@hotmail.fr, y.mabrouki@ump.ac.ma
}

Received: 09 July 2018; returned for review: 25 October 2018; accepted: 29 March 2019.

Monitoring amphibian populations, especially over fragile ecosystems such as arid and semiarid landscapes, helps to detect demographic trends and ecological risks. During several campaigns carried out between 2013 and 2017 across the Moulouya River Basin and the Oriental Region of Morocco, we identified nine amphibian species from the 11 previously recorded. Amphibian population threats were also detected. In this work, we focused on the amphibians of the Oriental Region of Morocco with the aims to (1) update their distribution providing new records, (2) confirm the prevalence of some vulnerable species in the region, and (3) provide an overview of the ecology and conservation status of each species at a regional level.

Key words: conservation; endemic species; faunistic inventory; Gambusia; habitat loss; new records.

Amphibian population declines are observed worldwide (BLAUSTEIN \& WAKE, 1990; Stuart et al. 2004). These declines are generally driven by the combination of climate change, chemical pollution, infectious diseases, habitat degradation and introduction of predators (KIESECKER et al., 2001; Blaustein et al., 2003, Daszak et al., 2003). In the last decades, many species have seen their numbers diminished, suffering local or complete extinctions (Houlahan et al., 2000).

Amphibians constitute a key component of vertebrate diversity in the western Mediterranean, representing the most vul- nerable group among vertebrates (Anthony et al., 2008). Particularly, amphibian diversity in northern Africa is formed by groups originated from different biogeographic regions. Species richness of Morocco differs from most of the African countries by the presence of a high proportion of relict elements of Eurosiberian origin, several of which are currently endemic (Schleich et al., 1996; Beukema et al., 2013; Reques et al., 2013). Unfortunately, many threats are having profound effects on this particular diversity that inhabits aquatic ecosystems and wetlands. In this sense, the Oriental Region of Morocco and 
the Moulouya River Basin are suffering from severe environmental degradation by domestic, industrial and agricultural pollution sources (Mabrouki et al., 2016a, 2017a; TAYBi et al., 2016a; BENSAAD et al., 2017; YAHYA et al., 2017). These anthropic pressures over the few wetlands present in the arid eastern Morocco result in significant disturbances to the local biodiversity (Maвrouki et al., 2016b; ТАүві et al., 2016b, 2017a).

Eleven species of amphibians have been recorded within the Oriental Region and the Moulouya River Basin (Bons \& Geniez, 1996; Beukema et al., 2013; MediANI et al., 2015). Among them, one species is considered as Vulnerable (Salamandra algira), three as Near Threatened (Pleurodeles waltl, Alytes maurus and Barbarophryne brongersmai), and six as of Least Concern (Discoglossus pictus, Discoglossus scovazzi, Bufotes boulengeri, Sclerophrys mauritanica, Hyla meridionalis and Pelophylax saharicus) based on IUCN Red List criteria. The conservation status of Bufo spinosus, currently considered a distinct species from $B$. bufo (Recuero et al. 2012), has not been eval- uated at a global level; however, Pleguezuelos et al. (2010) suggested that Moroccan populations of the common toad could be considered as Near Threatened (Table 1).

Basic information from distribution data within a temporal framework together to the identification of species potential threats are important starting points for monitoring amphibian populations and help to detect population trends and threats. It also could allow for identification of broad ecological problems related to global change (Stuart et al., 2008). This work aims to contribute to the knowledge of amphibians in the Oriental Region of Morocco by (1) updating their distribution and providing new records, (2) confirming the prevalence of some vulnerable species in the region, and (3) providing an overview of the ecology and conservation status of each species at a regional level.

\section{Materials and Methods}

\section{Study area}

The field work was carried out over the Oriental Region of Morocco, one of the 12 regions of the country that extends along

Table 1: Amphibian species of Eastern Morocco .

\begin{tabular}{lllcc}
\hline Order & Family & Species & IUCN category & Detected \\
\hline Caudata & Salamandridae & Salamandra algira Bedriaga, 1883 & Vulnerable & No \\
& & Pleurodeles waltl Michahelles, 1830 & Near Threatened & No \\
Anura & Alytidae & Alytes maurus Pasteur \& Bons, 1962 & Near Threatened & Yes \\
& Bufonidae & Barbarophryne brongersmai (Hoogmoed, 1972) & Near Threatened & Yes \\
& & Bufo spinosus Daudin, 1803 & Not evaluated & Yes \\
& & Sclerophrys mauritanica (Schlegel, 1841) & Least Concern & Yes \\
& & Bufotes boulengeri (Lataste, 1879) & Least Concern & Yes \\
& Discoglossidae & Discoglossus pictus Otth, 1837 & Least Concern & Yes \\
& & Discoglossus scovazzi Camerano, 1878 & Least Concern & Yes \\
& Ranidae & Pelophylax saharicus (Boulenger, 1913) & Least Concern & Yes \\
& Hylidae & Hyla meridionalis Boettger, 1874 & Least Concern & Yes \\
\hline
\end{tabular}




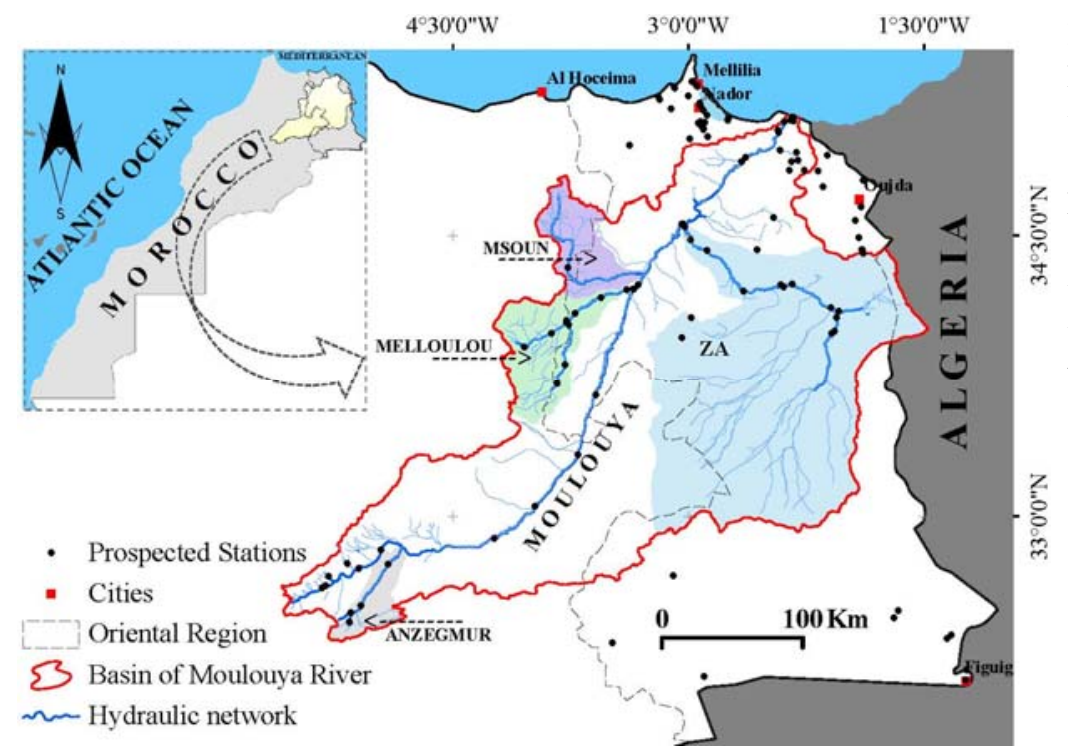

Figure 1: Sampled localities of the Oriental Region of Morocco and the Moulouya River Basin. For a correct visualization, the reader is referred to the online, colored version of the article.

most of the eastern side (Fig. 1). This region covers $90127 \mathrm{~km}^{2}$ (see TAYBI et al., $2017 \mathrm{~b}$ ), and is formed by the wilaya of Oujda (Oujda-Angad prefecture) and the provinces of Berkane, Taourirt, Jerada, Nador, Figuig, Driouch and Guercif. The watershed of the Moulouya (Fig. 1), with an area of $43412 \mathrm{~km}^{2}$, covers a great portion of the Oriental Region. Moulouya River is the largest Moroccan river that flows into the Mediterranean, extending along $600 \mathrm{~km}$. The principal tributaries of Moulouya river are the Oued Ansegmir, Melloulou, Za and Msoun, all of which are permanent, while other minor tributaries flow sporadically (3-5 flashfloods on average per year) (MABRouki et al., 2016b).

\section{Field surveys and mapping}

Field surveys were carried out between 2013 and 2017. A total of 103 localities were sampled (Table S1), including 45 within the Moulouya watershed (18 in the main river; 4 in the Oued Anzegmir, High
Atlas; 11 in the Oued Melloulou, Middle Atlas; and 12 in the Oued Za, High Plateau) and 58 over other areas of the Oriental Region (25 in the Oujda prefecture in the north-east, 24 in the Nador province in the north, and 9 in the Figuig province in the south). Data about the environmental impacts affecting some of these sampling sites are also provided by MABrouki et al. (2016a,b, 2017a,b) and ТАҮвi et al. (2016a,b, 2017a,b, 2018).

Tadpoles were collected using a dip net, fixed and preserved in ethanol for subsequent identification. Adults and juveniles were not collected, and were directly identified in the field.

Maps of the study region were made using ArcGIS software. For species' range maps, we used the available published information (Bons \& Geniez, 1996; Vences et al., 2014; Beukema et al., 2013; Mediani et al., 2015) and completed them with the records identified from the present study. 
Figure 2: Distribution maps of the amphibian species found during the course of the study. Photos: authors.
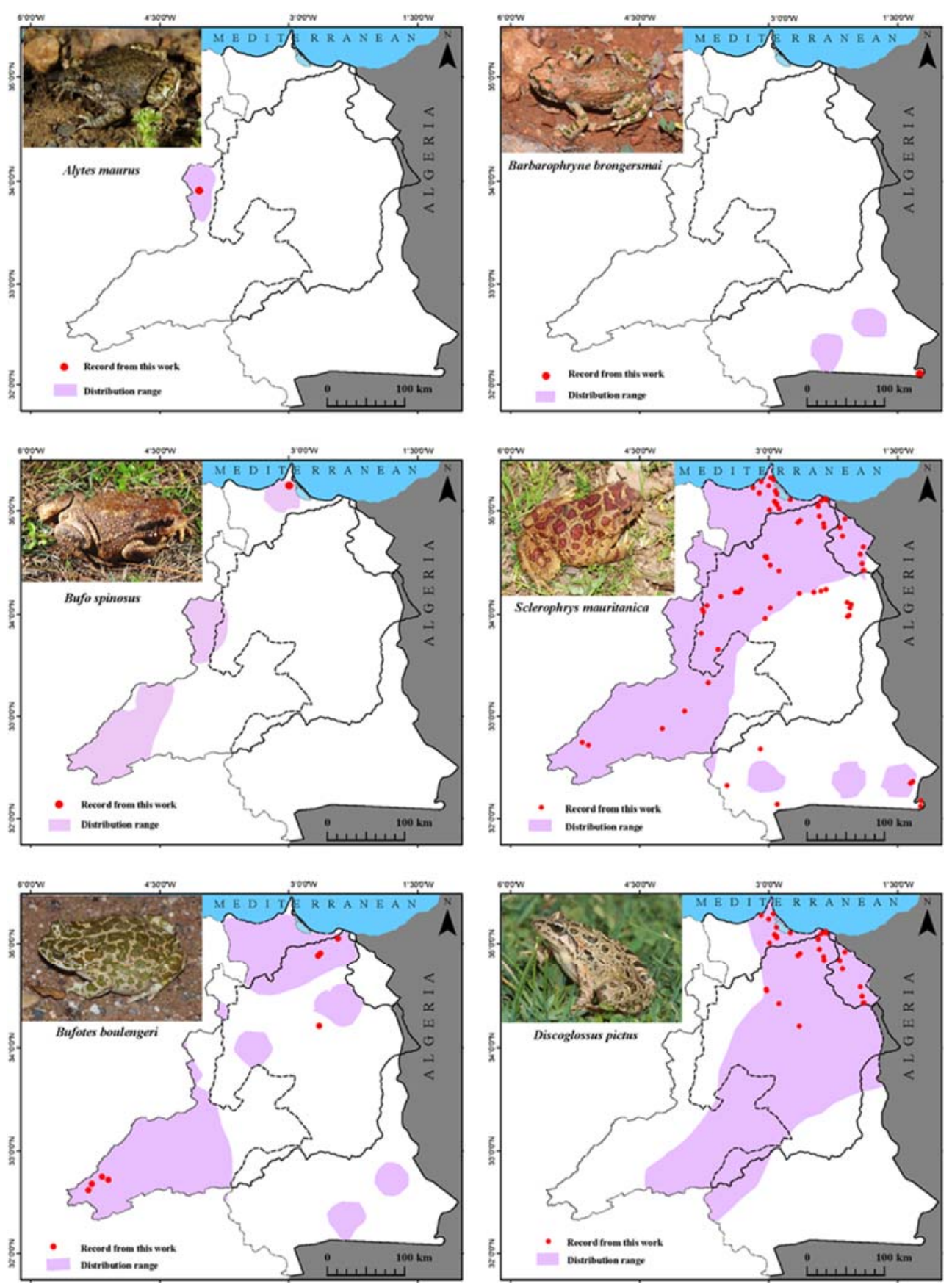
Figure 2 (cont.)
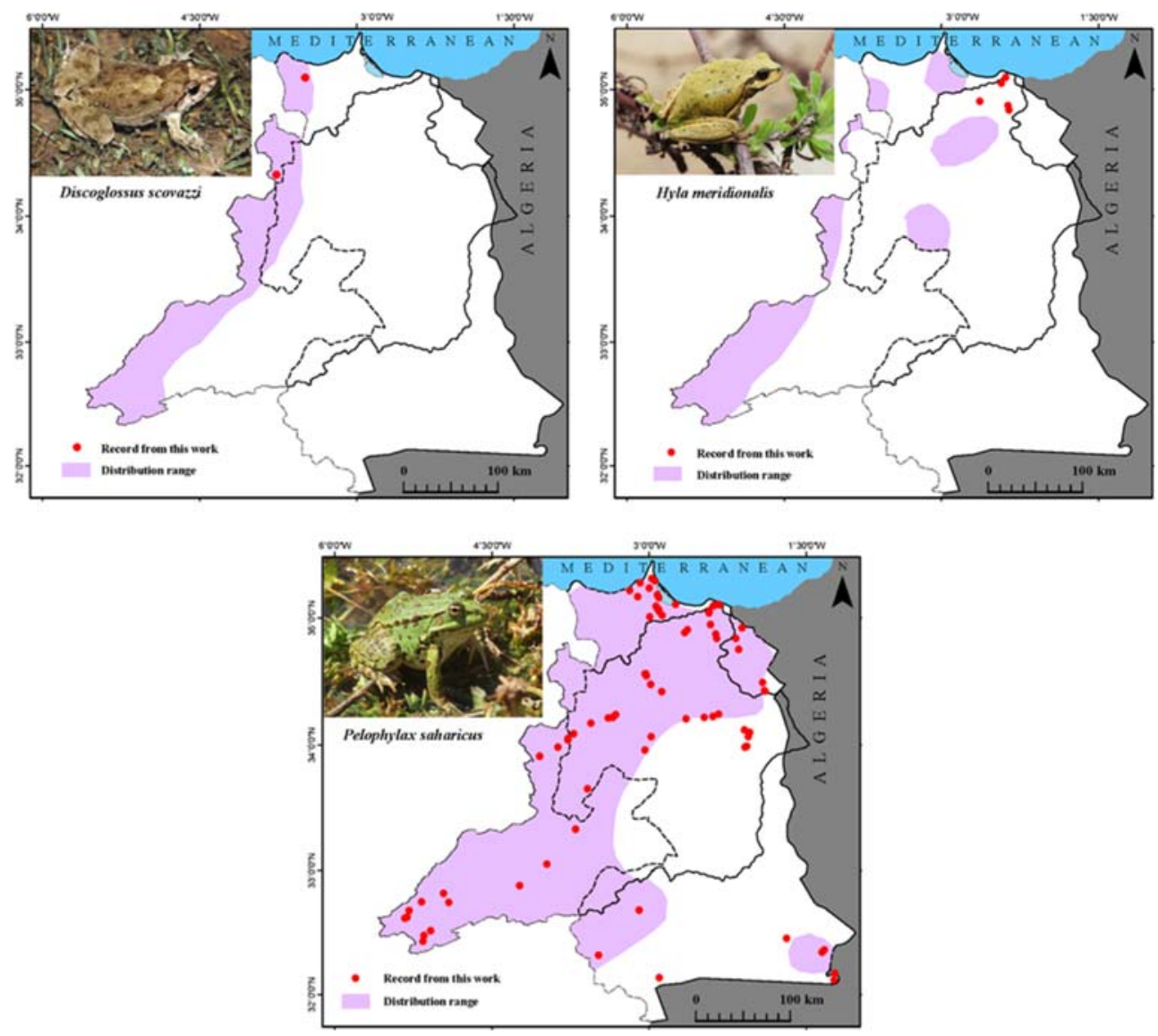

\section{Results And Discussion}

\section{General results}

Nine of the 11 amphibian species reported in the Oriental Region were found during our field surveys (Table 1). Two taxa were not found during our field surveys: S. algira spelaea Escoriza and Comas, 2007 and Pleurodeles waltl (Michahelles, 1830), which are listed as Vulnerable and Near Threatened, respectively, being therefore two of the most threatened amphibians of the Region. Distribution maps for each detected species are shown in Fig.
2.

Several local threats have been found in the study region, including (1) deforestation in the Gourougou forest, (2) intensification of agriculture over the high and the low Moulouya, (3) use of fertilizers and pesticides along the plain of Triffa, and (4) water pollution by wastewaters and drainage of water bodies in the watershed of the $\mathrm{Za}$ river and in the Nador lagoon. The latter specially affects to species that occur in large water bodies such as $S$. mauritanica and $P$. saharicus.

During the breeding season of S. mau- 
ritanica, we found a high mortality caused by road traffic in the northern region, at Selouan and Beni Snassen (Fig. 3). This could represent a local threat that affects populations inhabiting close to the roads and / or crossing them during breeding migrations, as noted in the Iberian Peninsula for different species (Matos et al., 2012). Infrastructures like water cisterns and irrigation channels have been also recorded in some sites within the Oriental Region, including Bni Tadjjite (geographic coordinates $\left.32.313743^{\circ} \mathrm{N}, \quad 3.47864^{\circ} \mathrm{W}\right)$, Selouan $\left(35.074753^{\circ} \mathrm{N}, 2.927405^{\circ} \mathrm{W}\right)$ and Oujda (locality O6, Table S1), where a considerable number of adults, tadpoles and juveniles of S. mauritanica and D. pictus were found dead, probably because of drowning. Similar observations have been reported in water cisterns from western Morocco (García-CARdenete et al., 2014).

The occurrence of exotic species can also bring severe threats to the amphibian diversity and population stability. In fact, several individuals of the American freshwater fish genus Gambusia (Actinopterygii: Poeciliidae) have been found during our surveys in the handled hydrosystems (i.e. irrigation channels or dams) from the eastern Rif to Figuig surroundings (Fig. 4). Moreover, we detected these invasive fish in protected areas such as SIBE (Site of Biological and Ecological Interest) or Ramsar sites, including the wetlands of the Moulouya River mouth, the Nador lagoon (Marchica) and the Mohamed V Dam. The presence of this exotic fish species could have severe consequences for native amphibians (e.g. DonaireBarroso \& Bogaerts, 2003; de Pous et al., 2012).
Some of the records of the present study are of special interest. Bufo spinosus has ben rediscovered at the massif of Gourougou. The easternmost localities of B. spinosus in Morocco had been recorded at the Gourougou Mountains (Yus Ramos \& Cabo Hernández, 1986) and the Beni Snassen Massif (Mellado \& Mateo, 1992). However, these records were unconfirmed as no additional specimens had been found after the original discovery, and, as suggested by Beukema et al., (2013), the presence of this species in Beni Snassen is still doubtful and needs confirmation. During a rainy day, we found a single $B$. spinosus individual close to a small, semitemporary stream on a mountain slope of Gourougou Massif (locality N10, Table S1). The low abundance and detectability of this species in the Gourougou region emphasizes the need to conserve the permanent and semi-permanent water points as breeding habitats for the species. In this sense, deforestation represents the main threat to this species in the Gourougou Massif (see the Data by species section below). Additional records of special interest found during the present study are some discovered populations of $H$. meridionalis from the arid extreme of northeastern Morocco, which fill a gap over its distribution in the Oriental Region. These new records based on adult specimens suggest that this species could occur in other unknown and arid localities between Morocco and Tunisia.

\section{Data by species}

Alytes maurus is confined to the humid mountainous areas of northern Morocco encompassing the Rif and the Middle At- 
las regions (Bons \& Geniez, 1996). In the study area, this species has been recorded in the eastern Middle Atlas. Adults inhabit open forest, rocky valleys, cork oak forest and agricultural terraces close to permanent streams, pools and other water bodies (Mediani et al., 2015). We recorded a single specimen in the upstream of Melloulou River, in the Eastern Middle Atlas (locality S1, Table S1). The specimen was found close to a small mountain stream with vegetated banks and supplied mainly by the snowmelt. This region is characterized by a humid bio-climate zone. Alytes maurus is listed as Near Threatened by the IUCN. Despite the lack of data on population trends, its narrow distributional range (less than $5000 \mathrm{~km}^{2}$ ) together with its sensitivity to chytridiomycosis (DonaIReBarroso et al., 2009a; Fisher et al., 2009),

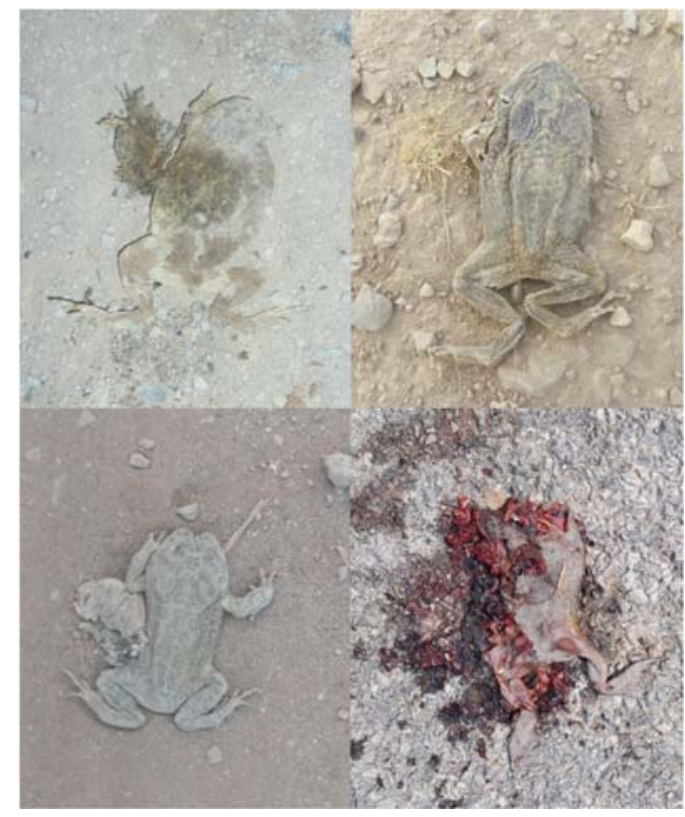

Figure 3: Examples of individuals of Sclerophrys mauritanica found dead on the road over the study area. Photos: authors. could suggest that a reevaluation of its conservation status would be necessary. The main threats to this species found in the study area are agricultural practices, habitat destruction, deforestation and unreasonable pumping of water for irrigation or domestic use (Fig. 5).

Barbarophryne brongersmai is an endemic species of the western Maghreb (Morocco and western Algeria). In Morocco, it is mainly distributed across the southern Anti-Atlas region and Souss Valley, with localized and dispersed populations over the northern High Atlas (Bons \& Geniez, 1996). Within the Oriental Region, it has been recorded from Figuig surroundings (Bons \& Geniez, 1996). It is found in semiarid landscapes with grasses in rocky areas and also inhabits anthropized areas such as crop fields or small dams (Schleich et al., 1996). We provided an additional record (locality F4, Table S1), based on a single specimen that was found buried under a rock. The habitat where the specimen was found is formed by permanent streams with small ponds remaining in the major riverbed after the regression of the water level. According to the IUCN criteria, $B$. brongersmai is classified as Near Threatened, due to the alarming loss and contamination of the breeding water bodies in semiarid landscapes. The presence of Gambusia has been detected in the irrigation system of the surroundings of Figuig where the species occurs.

In Morocco, B. spinosus is mainly found in the Rif, Middle Atlas and High Atlas, with scattered records in the Mediterranean coast (Bons \& GeNIEz, 1996; BeUкема et al., 2013). Within the Oriental Region, the species has been scarcely report- 
ed; there are doubtful records in the BeniSnassen and Nador surroundings (Mellado \& Mateo, 1992; Beukema et al., 2013). Moroccan populations of B. spinosus are confined to the wettest and coolest areas of the country, where it breeds in permanent or mostly permanent water bodies (Bons \& Geniez, 1996; SÁnchezVIALAs et al., 2016). During our surveys, we found a single adult male in the Gourougou Mountain (locality N10, Table S1) close to a small and semi-temporary stream. Currently, B. spinosus is considered a distinct taxon from B. bufo (which is classified as of Least Concern by the IUCN) and its conservation status has not been evaluated by the IUCN. However, it has been suggested that Moroccan populations of B. spinosus could be considered as Near Threatened (Pleguezuelos et al., 2010; Reques et al., 2013). Indeed, a special conservation emphasis should be given to the Mediterranean populations of B. spinosus. The Gourougou forest is subject to a high anthropic pressure, driven by urban

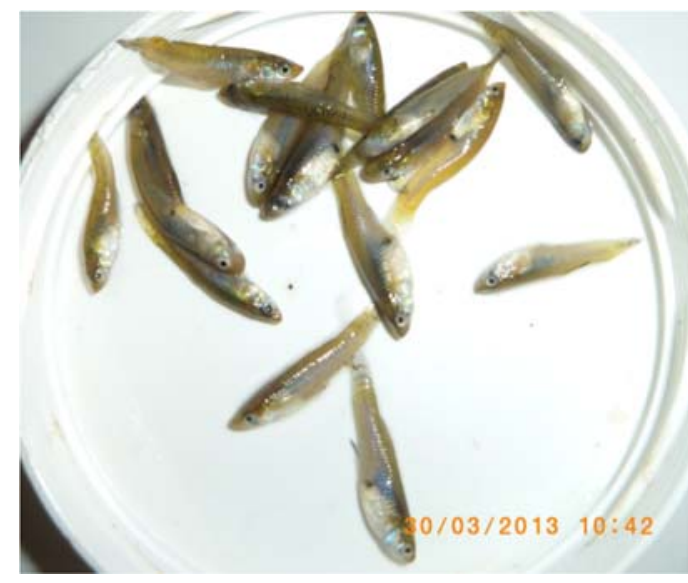

Figure 4: Gambusia specimens collected from the Lower Moulouya (locality M21, see Table S1). Photo: authors. development, habitats loss, deforestation and fires.

The Maghrebian endemism Sclerophrys mauritanica is one of the most widespread and abundant amphibians in Morocco (Beukema et al., 2013). It occupies different water bodies like streams and pools, with the exception of the smallest ones, where it is commonly replaced by $B$. boulengeri or B. brongersmai (SCHOuten \& Thevenot, 1988). However, it is rare or absent in the Sahara region (Bons \& GENIEz, 1996). We recorded S. mauritanica at several localities where it seems to be abundant (localities M4, M5, M11, M12, M13, M14, M15, M16, M17, M18, M19, M20, M21, M22, S5, S6, S7, S8, S9, S10, S11, Z1, Z2, Z3, Z4, Z5, Z6, Z7, Z8, Z9, Z10, $\mathrm{Z11}, \mathrm{Z12}, \mathrm{O} 1, \mathrm{O} 2, \mathrm{O} 3, \mathrm{O} 4, \mathrm{O} 5, \mathrm{O} 6, \mathrm{O} 7, \mathrm{O} 8$, O9, O10, O11, O12, O13, O14, O15, O16, O17, N1, N2, N3, N4, N5, N6, N7, N8, N9, N10, N11, N12, N13, N14, N15, F2, F3, F4, F5, F7, F8 and F9, Table S1). Within the Oriental Region, the species has been found occupying most of the aquatic environments, including the lentic portions of large rivers, small mountain streams, coastal areas such as the wetlands of the Moulouya River mouth and the Nador lagoon, and even within urban areas. It is cataloged by the IUCN as of Least Concern because of its wide distribution, relative tolerance to anthropic disturbances, wide ecological niche and presumed high abundance (Donaire-Barroso et al., 2009b). We have detected several local threats such as habitat destruction, water pollution (Fig. 5), and also the occurrence in its breeding habitats of Gambusia (Fig. 4), which is especially common in the SIBE and protected areas, like the lagoon of 


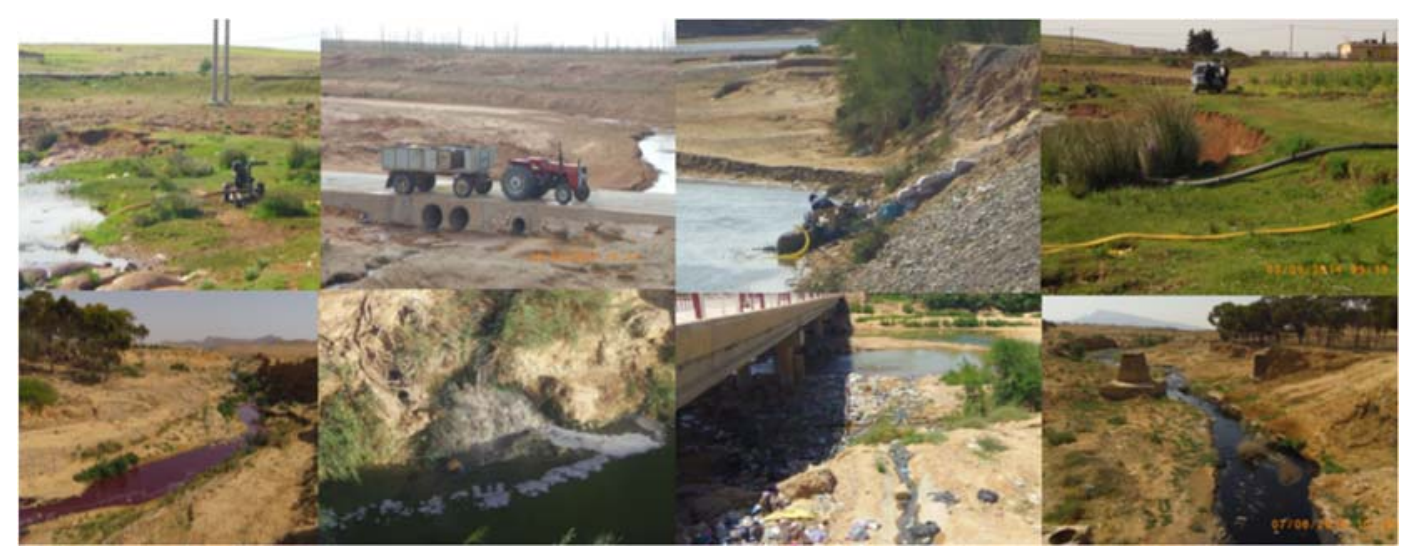

Figure 5: Examples of activities contributing to alteration or destruction of aquatic habitats. Top pictures show excessive pumping water at (from left to right): Krouchene (locality M4), pond Oued Charef (locality Z2), Douar Imzaghrou (locality S8), and Ait Boulman (locality M1). Bottom pictures show different sources of pollution in water bodies at several localities of the study area (from left to right): industrial wastewater close to locality Z11, industrial wastewater close to locality N5, solid pollution and domestic wastewater at locality M12, and domestic wastewater near the locality Z11. For details on localities, see Table S1. Photos: authors.

Nador and several ponds over the mouth of the Moulouya River.

Bufotes boulengeri occupies a vast area in northern Africa. It is one of the most common and widely distributed amphibians species of Morocco (GARcía-MuÑoz et al., 2010). In the Oriental Region, it has been recorded in large numbers at several localities (Bons \& GENIEz, 1996) across different habitats, ranging from more or less brackish coastal marshes to dams and artificial ponds. It is also found in urban and agricultural landscapes (localities M3, M4, M5, M19, M20, M21 and Z9, Table S1). According to the IUCN criteria, B. boulengeri is classified as of Least Concern (MartínezSolano et al., 2008). Over the Oriental Region, we have detected several conservation problems for this species, like intense road traffic during the wet season, loss of breeding sites because of drainage of wetlands, and desiccation or contamination of water bodies (Fig. 5). Furthermore, the use of wetlands as landfills, the high environmental pressure of livestock, and the discharge of wastewater from nearby residential areas to wetlands, constitute severe threats to the habitats of this species.

Discoglossus pictus is distributed over both insular (Sicily, Malta, Gozo, and some islands close to Tunisia) and continental regions, where it is spread throughout northwestern Africa. African populations range from the Moulouya River Basin to Tunisia (Ben Hassine \& Nouira, 2012). Its presence in Morocco is restricted to the Oriental Region (Vences et al., 2014), mostly at the east of the Moulouya Basin (localities M18, M19, M20, M21, M22, Z9, Z10, Z12, O3, O4, O5, O7, O8, O9, O10, O11, O12, O13, O14, O15, O16, O17, N1, N2, N3, N4, N5, N6, N8, N9, N10 and N11, Table S1). Some of these localities present different climatic conditions, ranging from 
the semi-arid landscapes of the Moulouya Valley and Marchica Lagoon to the subhumid climate in the upper areas of the Beni Snassen. Discoglossus pictus is considered as of Least Concern according to the IUCN criteria. It is an abundant species that occurs in wetlands of the Oriental Region; in arid zones, it is linked to the existence of mostly permanent waters (springs and troughs). We found that the water cisterns could represent a local threat for some populations because they work as traps for adults and juveniles. At locality O6, dozens of adult and metamorphic individuals were found dead together with hundreds of tadpoles during the dry season.

Discoglossus scovazzi is a Moroccan endemism that has been considered traditionally as a subspecies of D. pictus (e.g. LANZA et al., 1986). However, despite its parapatric distribution in Morocco, D. scovazzi and $D$. pictus are not sister species (Pabijan et al., 2012). The western areas of the Moulouya River Basin represent a secondary contact zone between both species (Vences et al., 2014). Within the study area, we have found this species in the Middle Atlas and eastern Rif (localities N23 and N24, Table S1), at locations close to streams. Listed as of Least Concern according to the IUCN criteria, their major threats found in the Moulouya River Basin are related to water overexploitation and pollution from the discharges of untreated domestic wastewater to natural wetlands (Fig. 5).

Pelophylax saharicus is a common amphibian species in Morocco, occupying several bioclimatic levels. In the southern region of Morocco, its distribution range is very fragmented, formed by isolated populations that occur close to water bodies (mostly permanent) (e.g. Laâyoune and surroundings) (Bons \& Geniez, 1996). It is one of the most widespread amphibians in the study area. It was found in almost all water bodies, from streams and large rivers to temporary ponds and lagoons, being also frequent in artificial water pools (localities M1, M2, M3, M4, M5, M6, M7, M8, M9, M10, M11, M12, M13, M14, M15, M16, M17, M18, M19, M20, M21, M22, S2, S3, S4, S5, S6, S7, S8, S9, S10, S11, Z1, Z2, Z3, Z4, Z5, Z6, Z7, Z8, Z9, Z10, Z11, Z12, O1, O2, O3, O4, O5, O6, O7, O8, O9, O10, O11, O12, O13, O14, O15, O16, O17, N1, N2, N3, N4, N5, N6, N7, N8, N9, N10, N11, N12, N13, N14, N15, F1, F2, F3, F4, F5, F6, F7, F8 and F9, Table S1). According to the IUCN criteria, P. saharicus is cataloged as of Least Concern (DonAIREBARroso et al., 2008). In spite of its abundance, populations from the Oriental Region have been severely affected by habitat degradation and destruction, which are mainly linked to the urban expansion (such as in Nador), as well as by wetland desiccation, overexploitation and pollution from domestic and industrial effluents (Fig. 5).

Hyla meridionalis is distributed over the western Mediterranean. In Morocco, it is widespread throughout the northern region (Bons \& Geniez, 1996; Barnestein et al., 2010). It can be found in trees, shrubs, fruit trees and pastures, usually near freshwater habitats during the breeding season. We recorded this species at five localities in Berkane area where it had not been recorded previously (localities M20, M21, M22, O4 and O12, Table S1). Some adult 
males were found calling on fruit trees during daytime at Beni Snassen, while at the Lower Moulouya adults were found over the waterside vegetation (e.g. Typha latifolia). An individual was found dead at Pont Hassan II. Hyla meridionalis is listed as of Least Concern by the IUCN because it presents a wide distribution, can occur at different habitat types, and presumably has high population densities (DonAIREBARroso et al., 2009c). In the study area, we have observed habitat loss because of agricultural intensification (especially in the river bank of the localities $\mathrm{O} 4$ and O12), infrastructure development (near the SIBE of Moulouya, locality O7) and pollution of aquatic habitats. The introduction and expansion of Gambusia (Fig. 4) over most part of the Lower Moulouya represents an additional local threat.

\section{Acknowledgement}

We would like to thank all the local people for their help and involvement during the fieldwork.

\section{REFERENCES}

Anthony, B.; Arntzen, J.W.; El Din, S.B.; Böhme, W.; Cogălniceanu, D.; CrnobrnjaIsailovic, J.; Crochet, P.A.; Corti, C.; Griffiths, R.; Kaneko, Y.; Kuzmin S.; LaU, M.W.N.; Li, P.; Lymberakis, P.; Márquez, R.; Papenfuss, T.; Pleguezuelos, J.M.; Rastegar, N.; Schmidt, B.; Slimani, T.; Sparreboom, M.; Ugurtas, I.; Werner, Y. \& XIE, F. (2008). Amphibians of the Palaearctic Realm, In S. Stuart, M. Hoffman, J. Chanson, N. Cox, R. Berridge, P. Ramani \& B. Young (eds.) Threatened Amphibians of the World. Lynx Edicions and IUCN-The World Conservation Union, Bellaterra, Spain, pp. 106-113.

Barnestein, J.A.M.; GonZÁlez de la Vega, J.P.;
Jiménez-Cazalla, F. \& Gabari-BoA, V. (2010). Contribución al atlas de la herpetofauna de Marruecos. Boletín de la Asociación Herpetológica Española 21: 76-82.

Ben Hassine, J. \& Nouira, S. (2012). Répartition géographique et affinités écologiques des Amphibiens de Tunisie. Revue d'Ecologie 67: 437-457.

BensaAd, H.; Mabrouki, Y.; TAybi, A.F. \& Chafi, A. (2017). Assessment of wastewater discharges from Taourirt City on the water quality of the Oued Za (Eastern Morocco). Journal of Materials and Environmental Science 8: 2365-2371.

Beukema, W.; de Pous, P.; Donaire-Barroso, D.; Bogaerts, S.; García-Porta, J.; Escoriza, D.; Arribas, O.J.; El Mouden, E.H. \& Carranza, S. (2013). Review of the systematics, distribution, biogeography and natural history of Moroccan amphibians. Zootaxa 3661: 1-60.

Blaustein, A.R. \& WaKe, D.B. (1990). Declining amphibian populations: a global phenomenon? Trends in Ecology and Evolution 5: 203 $-204$.

Blaustein, A.R.; Romansic, J.M.; Kiesecker; J.M. \& НАтсн, A.C. (2003). Ultraviolet radiation, toxic chemicals and amphibian population declines. Diversity and Distributions 9: 123-140.

Bons, J. \& Geniez, P. (1996). Amphibiens et Reptiles du Maroc (Sahara Occidental Compris). Atlas Biogéographique. Asociación Herpetológica Española, Madrid, Spain.

Daszak, P.; Cunningham, A.A. \& Hyatt, A.D. (2003). Infectious diseases and amphibian population declines. Diversity and Distributions 9: 141-150.

de Pous, P.; Beukema, W.; Dingemans, D.; Donaire, D.; Geniez, P. \& El Mouden, E.H. (2012). Distributional review, habitat suitability and conservation of the endangered and endemic Moroccan spadefoot toad (Pelobates varaldii). Basic and Applied Herpetology 26: 57-71.

Donaire-Barroso, D. \& Bogaerts, S. 
(2003). Datos sobre taxonomía, ecología y biología de Alytes maurus (Pasteur \& Bons, 1962) (Anura; Discoglossidae). Butlletí de la Societat Catalana d'Herpetologia 16: 25-42.

Donaire-Barroso, D.; Martínez-Solano, I.; Salvador, A.; García-París, M.; Recuero Gil, E.; Slimani, T.; El Mouden, E.H.; GeNiez, P.; Slimani, T.; Joger, U. \& El Din, S.B. (2008). Pelophylax saharicus, In The IUCN Red List of Threatened Species 2009. International Union for Conservation of Nature, Gland, Switzerland. Available at https:// www.iucnredlistorg/. Retrieved on 15 December 2018.

Donaire-Barroso, D.; Salvador, A.; Slimani, T.; El Mouden, E.H. \& Martínez-Solano. I. (2009a). Alytes maurus, In The IUCN Red List of Threatened Species 2009. International Union for Conservation of Nature, Gland, Switzerland. Available at https:// www.iucnredlist.org/. Retrieved on 15 December 2018.

Donaire-Barroso, D.; Salvador, A.; MartínezSolano, I., García-París; M., Recuero Gil, E.; Slimani, T.; El Mouden, E.H.; Geniez, P. \& Joger, U. (2009b). Bufo mauritanicus, In The IUCN Red List of Threatened Species 2016. International Union for Conservation of Nature, Gland, Switzerland. Available at https://www.iucnredlist.org/. Retrieved on 15 December 2018.

Donaire-Barroso, D.; Beebee, T.; Beja, P.; ANdreone, F.; Bosch, J.; Tejedo, M.; Lizana, M.; Martínez-Solano, I.; Salvador, A.; García-París, M.; Recuero Gil, E.; Slimani, T.; El Mouden, E.H. \& Márquez, R. (2009c). Hyla meridionalis, In The IUCN Red List of Threatened Species 2009. International Union for Conservation of Nature, Gland, Switzerland. Available at https:// www.iucnredlist.org/. Retrieved on 15 December 2018.

Fisher, M.C.; Garner, T.W.J. \& Walker, S.F. (2009). The global emergence of Batrachochytrium dendrobatidis and amphibian chytridiomycosis in space, time and host. Annual
Review of Microbiology 63: 291-310.

García-Cardenete, L.; Pleguezuelos, J.M.; Brito, J.C.; Jiménez-Cazalla, F.; PérezGarcía, M.T. \& SAntos, X. (2014). Water cisterns as death traps for amphibians and reptiles in arid environments. Environmental Conservation 41: 341-349.

García-Muñoz, E.; Jorge, F.; Rato, C. \& CarreTERo, M.A. (2010). Four types of malformations in a population of Bufo boulengeri (Amphibia, Anura, Bufonidae) from the Jbilet Mountains (Marrakech, Morocco). Herpetology Notes 3: 267-270.

Houlahan, J.E.; Findlay, C.S.; Schmidt, B.R.; Meyer, A.H. \& Kuzmin, S.L. (2000). Quantitative evidence for global amphibian population declines. Nature 404: 752-755.

Kiesecker, J.M.; Blaustein, A.R. \& Belden, L.K. (2001). Complex causes of amphibian population declines. Nature 410: 681-684.

Lanza, B.; Nascetti, G.; Capula, M. \& Bullini, L. (1986). Les Discoglosses de la région méditerranéenne occidentale (Amphibia; Anura; Discoglossidae). Bulletin de la Société Herpétologique de France 40: 16-27.

Mabrouki, Y.; Taybi, A.F.; BensaAd, H. \& Berrahou, A. (2016a). Variabilité spatiotemporelle de la qualité des eaux courantes de l'Oued Za (Maroc Oriental). Journal of Materials and Environmental Science 7: 231243.

Mabrouki, Y.; Taybi, A.F.; Chavanon, G.; Vinçon, G. \& Berrahou, A. (2016b). Contribution à l'étude des plécoptères dans le Maroc Oriental et le bassin versant de la Moulouya et leur distribution en fonction des étages bioclimatiques. Journal of Materials and Environmental Science 7: 2178-2193.

Mabrouki, Y.; Taybi A.F. \& Berrahou, A. (2017a). L'évolution spatio-temporelle de la qualité des eaux courantes de l'Oued Melloulou (Maroc). Revue des Sciences de l'Eau 30: 213-225.

Mabrouki, Y.; Taybi, A.F.; El Alami, M. \& Berrahou, A. (2017b). New and interesting data on distribution and ecology of mayflies 
from Eastern Morocco (Ephemeroptera). Journal of Materials and Environmental Science 8: 2832-2859.

Martínez-Solano, I.; Sindaco, R. \& Romano, A. (2008). Bufotes boulengeri, In The IUCN Red List of Threatened Species 2015. International Union for Conservation of Nature, Gland, Switzerland. Available at https:// www.iucnredlist.org/. Retrieved on 15 December 2018.

Matos, C.; Sillero, N. \& Pérez, E.A. (2012). Spatial analysis of amphibian road mortality levels in northern Portugal country roads. Amphibia-Reptilia 33: 469-483.

Mediani, M.; Brito, J.C. \& FAhD, S. (2015). Atlas of the amphibians and reptiles of northern Morocco: updated distribution and patterns of habitat selection. Basic and Applied Herpetology 29: 81-107.

Mellado, J. \& Mateo, J.A. (1992). New records of Moroccan herpetofauna. Herpetological Journal 2: 58-61.

Pabijan, M.; Crottini, A.; Reckwell, D.; IrisarRI, I.; Hauswaldt, J.S. \& Vences, M. (2012). A multigene species tree for Western Mediterranean painted frogs (Discoglossus). Molecular Phylogenetics and Evolution 64: 690-696.

Pleguezuelos, J.M.; Brito, J.C.; Fahd, S.; Feriche, M.; Mateo, J.A.; Moreno-Rueda, G.; Reques, R. \& Santos, X. (2010). Setting conservation priorities for the Moroccan herpetofauna: the utility of regional red listing. Oryx 44: 501-508.

Recuero, E.; Canestrelli D.; Vörös J.; Szabó K.; Poyarkov, N.A.; Arntzen, J.W.; CrnobrNJA-Isailovic, J.; Kidov A.A.; CogǍlniceanu, D.; Caputo, F.P.; Nascetti, G. \& MarTínez-Solano, I. (2012). Multilocus species tree analyses resolve the radiation of the widespread Bufo bufo species group (Anura, Bufonidae). Molecular Phylogenetics and Evolution 62: 71-86.

Reques, R.; Pleguezuelos, J.M.; Busack, S.D. \& De Pous, P. (2013). Amphibians of Morocco, including Western Sahara: a status report.
Basic and Applied Herpetology 27: 23-50.

SÁnChez-Vialas, A.; Jiménez-Robles, O.; DEL Mármol, G.M. \& León, R. (2016). Contribution to the reproductive biology of Bufo spinosus in Morocco. Boletín de la Asociación Herpetológica Española 27: 18-20.

Schleich, H.H.; Kastle, W. \& Kabisch, K. (1996). Amphibians and Reptiles of North Africa. Koeltz Scientific Publishers, Koenigstein, Germany.

Schouten, J.R. \& Thevenot, M. (1988). Amphibians and reptiles of the Khnifiss-La'Youne region, In M. Dakkim \& W. De Ligny (eds.) The Khnifiss Lagoon and its Surrounding Environment (Province de La'Youne, Morocco). Series: Travaux de l'Institut Scientifique de Rabat. l'Institut Scientifique de Rabat, Rabat, Morocco, pp. 100-114.

Stuart, S.N.; Chanson, J.S.; Cox, N.A. \& Young, B.E. (2004). Status and trends of amphibian declines and extinctions worldwide. Science 306: 1783-1786.

Stuart, S.N.; Hoffman, M.; Chanson, J.S.; Cox, N.A.; Berridge, R.J.; Ramani, P. \& Young, B. (2008). Threatened Amphibians of the World. Lynx Edicions and IUCN-The World Conservation Union, Bellaterra, Spain.

Taybi, A.F.; Mabrouki, Y.; Berrahou, A. \& ChaAbane, K. (2016a). Évolution spatiotemporelle des paramètres physicochimiques de la Moulouya. Journal of Materials and Environmental Science 7: 272284.

Taybi, A.F.; Mabrouki, Y.; Berrahou, A.; PerisFelipo, F.J. \& ChaAbane, K. (2016b). Contribution à l'étude de la relation «plante -hôte-parasite» entre Elodea canadensis Michx., Hydrellia sp. (Diptera) et Ademon decrescens (Nees, 1811) (Hymenoptera, Opiinae) dans le bassin versant de la Moulouya (Maroc). Journal of Materials and Environmental Science 7: 2445-2452.

Taybi, A.F.; Mabrouki, Y.; Ghamizi, M. \& BerRAHOU, A. (2017a). The freshwater malacological composition of Moulouya's water- 
shed and Oriental Morocco. Journal of Materials and Environmental Science 8: 14011416.

Taybi, A.F.; Mabrouki, Y.; Chavanon, G.; Berrahou, A. \& Millán, A. (2017b). New data on aquatic beetles of Morocco (Coleoptera Adephaga: Gyrinidae, Haliplidae and Dytiscidae). Baltic Journal of Coleopterology 17: 83-106.

Taybi, A.F.; Mabrouki, Y.; Berrahou, A. \& Ait El Abed, A. (2018). Bio-ecology of Potamon algeriense (Herbst, 1785) (Crustacea, Decapoda) in the watershed of Moulouya and Oriental Morocco. Animal Biodiversity and Conservation 41: 267-274.

Vences, M.; de Pous, P.; Nicolas, V.; DíazRodríguez, J.; Donaire, D.; Hugemann, K.; Hauswaldt, J.S.; Амat, F.; Barnestein
A.M.J.; Bogaerts, S.; Bounzza, A.; Carranza, S.; Galán, P.; González de la Vega, J.P.; Joger, U.; Lansari, A.; El Mouden, E.H.; Ohler, A.; Sanuy, D.; Slimani, T. \& Tejedo, M. (2014). New insights on phylogeography and distribution of painted frogs (Discoglossus) in northern Africa and the Iberian Peninsula. Amphibia-Reptilia 35: 1-12.

YAHYA, H.S.A.; TаYвI, A.F.; Mabrouki, Y.; FAhsi, A.; Chafi, A. \& ChafiK, Z. (2017). The metallic pollution in the groundwater of Triffa Plain (Eastern Morocco). Journal of Materials and Environmental Science 8: 3372-3381.

Yus Ramos, R. \& Cabo Hernández, J.M. (1986). Guia de la Naturaleza de la Región de Melilla. Excmo. Ayuntamiento de Melilla, Melilla, Spain. 